\title{
WATER DEFICIENCY TOLERANCE OF GENETICALLY MODIFIED COMMON WHEAT CV. ZYMOYARKA, CONTAINING A HETEROLOGOUS ORNITHINE- $\Delta$-AMINOTRANSFERASE GENE
}

\author{
O. V. Dubrovna, G. O. Priadkina, S. I. Mykhalska, A. G. Komisarenko \\ Institute of Plant Physiology and Genetics NAS of Ukraine \\ 31/17, Vasylkivska Str., Kyiv, Ukraine, 03022
}

E-mail:dubrovny@ukr.net*,galpryadk@gmail.com,mykhalskasvitlana@gmail.com,allakomisarenko2017@gmail.com

Received February 01, 2021 / Received March 01, 2021 / Accepted March 19, 2021

\begin{abstract}
Aim. To determine water deficiency tolerance of genetically modified common wheat plants (Triticum aestivum L., cv Zymoyarka), containing the heterologous ornithine- $\delta$-aminotransferase gene, based on the analysis of grain productivity and physiological and biochemical characteristics in transgenic and non-transgenic genotypes. Methods. Biochemical spectrophotometric assays: the enzyme ornithine- $\delta$-aminotransferase activity, the free L-proline content, and the photosynthetic pigments content; biotechnological: Agrobacterium-mediated transformation in planta; physiological: morphometric traits and elements of grain productivity; mathematical statistics. Results. It was established that the presence of an additional copy of the ornithine- $\delta$-aminotransferase gene in transgenic plants leads to higher activity of the ornithine- $\delta$ aminotransferase enzyme: by 1.6 times higher on average for all lines as compared to the non-transgenic plants at $70 \%$ of field capacity and by 1.5 - at $30 \%$ field capacity. However, transgenic plants did not differ significantly from the original variety in the free L-proline content either under optimal water conditions or under soil drought. The increase in the total chlorophyll $(a+b)$ content in flag leaves of transgenic plants was established under conditions of both optimal water supply and drought, as compared with the original genotype (increase by $5-7 \%$ and $8-11 \%$, respectively). The enhanced expression of the ornithine- $\delta$-aminotransferase gene in the transgenic plants stimulated root growth both under optimal and stressful conditions: the root length of the transformed plants exceeded that of the original variety by $3.4-3.9 \mathrm{~cm}$ in the variant with optimal water supply, and by $4.2-4.6 \mathrm{~cm}$ - under drought. They were also characterized by a more developed root system. Dry root weight of the transgenic plants exceeded the original variety both in the control (by 23-27\%), and under drought (by $37-$ $44 \%$ ). Under drought, the root dry weight decreased by $29 \%$ in the plants of the original variety, compared $70 \%$ field capacity, and by $11-15 \%$ in the lines. Under $30 \%$ field capacity, the transgenic lines also exceeded non-transformed plants in the number of grains from the whole plant (on average for 3 lines by $26 \%$ ) and in the grain weight (by $22 \%$ ). Transgenic plants are characterized by the formation of a higher productive shoots number: from 3.2 to 3.4 compared with 2.5 in non-transgenic plants at $70 \%$ field capacity and $2.7-3.1$ vs 2.2 at $30 \%$ field capacity it was found. Conclusions. Thus, the analysis of genetically modified common wheat plants cv. Zymoyarka, containing the heterologous alfalfa ornithine- $\delta$ aminotransferase gene, by yield structure elements, morphometric parameters and photosynthetic pigment content showed their better tolerance to soil drought as compared to non-transgenic plants. We explain the improvement of grain productivity of the whole plant in transgenic wheat lines with an additional copy of ornithine- $\delta$-aminotransferase gene by the fact that they have a better developed root system (dry root weight of the transgenic plants exceeded the original variety both in the control by $23-27 \%$, and under drought by $37-44 \%$ ) and a higher (on average for 3 lines -3.3 compared to 2.5 in nontransgenic plants at $70 \%$ field capacity and 2.9 vs 2.2 at $30 \%$ field capacity) number of productive shoots than in the original variety both under optimal and insufficient water supply.
\end{abstract}

Key words: wheat, transgenic plants, proline metabolism gene, soil drought, photosynthetic pigments, grain productivity.

DOI: https://doi.org/10.15407/agrisp8.01.014

\section{INTRODUCTION}

Considerable recent changes in climatic conditions have had their negative influence on the productivity of cultivated plants (Sadras VO and Calderini DF, 2015;
Raza A et al, 2019). Since the beginning of this century, common winter wheat plants (Triticum aestivum L.) one the most relevant food crops - have been exposed to elevated temperatures and soil droughts more fre- 
quently (Barnábas B et al, 2008; Brisson N et al, 2010). For instance, the data of 30-year-long studies demonstrated that the influence of weather on grain productivity of common winter wheat varieties of German selection amounted to $13 \%$ (Laidig F et al, 2017). The mean for environmental variation (year, location and year by location) of $41 \%$ was only slightly larger than the genotypic variation $(40 \%)$.

The inhibition of the photosynthetic process and impaired reproductive development under drought cause a considerable loss of wheat grain productivity, which may be from 25 to $90 \%$, depending on the phenological stages and the severity, and duration of the stress influence (Farooq M et al, 2014; Zhang et al, 2018). Thus, the prevention of the negative effect of climatic changes on the productivity of common winter wheat requires breeding high-yielding varieties with high adaptive potential, including drought tolerance.

The application of gene engineering methods is a modern trend in breeding drought-resistant wheat varieties. An example of such methods is integrating recombinant DNA molecules, capable of controlling adaptation/resistance processes on the genetic level, into the genome of cultivated plants (Hiei Y et al, 2014). The use of genes that control the metabolism of "compatible" osmotically active substances - organic molecules capable of accumulating in significant concentrations in plant cells under conditions stress, without exerting a toxic effect on the processes of their growth and differentiation can be a promising direction for increasing their resistance to drought. One of the possible ways to create drought-resistant varieties is use of genes, controlling proline synthesis and catabolism (Vahdati K and Lotfi N, 2013; Anwar A et al, 2018) The additional synthesis of this amino acid enhances general resistance of plants to abiotic stress, because proline protects membranes, macromolecules, and cell structural elements, enhancing non-specific resistance (Szabados L and Savoure A, 2010; Senthil-Kumar M and Mysore K, 2012).

The adaptation of plants to unfavorable environmental conditions requires comprehensive genetic programs, involving the coordinated expression of large gene complexes (Tuberosa R and Salvi S, 2006; Tran LSP et al, 2007; Morgun VV et al, 2010; Fukao T and Xiong L, 2013). For instance, in response to stress, there are changes in the level of the expression of genes, controlling the metabolism of some aminoacids, such as proline, asparagine, arginine (Martinelli T et al, 2007). These genes include the ornithine- $\delta$-aminotransferase gene, encoding the enzyme (OAT, EC 2.6.1.13), which catalyzes the transfer of the delta-aminogroup of ornithine onto alpha-ketoglutarate with the formation of pyrroline-5-carboxylate (P5C) and glutamate (Stranska J et al, 2010; Anwar A et al, 2018). This response is one of interconversions of such aminoacids as arginine, ornithine, glutamate, and proline. The metabolism of these aminoacids is related to the fixation, storing, and remobilization of nitrogen, the formation and germination of seeds, the resistance to different abiotic stresses, the regulation of growth and development processes (Canas RA et al, 2008; Funck D et al, 2008; Mattioli R et al, 2009). Thus, ornithine- $\delta$-aminotransferase may be a relevant regulator of cell metabolism.

OAT is linked with the metabolic pathways of proline and arginine. The first step in arginine catabolism is the degradation of arginine into urea and ornitine by arginase. Then ornitine can enter either into the proline biosynthesis pathway, or it is transported to the chloroplast, where it takes part in the arginine biosynthesis pathway (Anwar A et al, 2018). The OAT is involved in stress-induced proline accumulation in cytoplasm, programmed cell death and non-host disease resistance in plants (Szabados L and Savoure A, 2010; Anwar A et al, 2020). The OAT enzyme is also involved in nitrogen metabolism as evidenced by proline metabolism showing positive correlation with nitrogen metabolism through two regulatory enzymes i.e OAT and P5CS, which is dependent on the nitrogen supply in plants (Funck D et al, 2008; Sánchez E et al, 2018). It was found than the homologue of $\delta O A T-O S O A T$ - in rice is essential for nitrogen reutilization through mediating arginase activity (Liu $\mathrm{C}$ et al, 2018). Through mediating nitrogen reutilization $\delta O A T$ influenced for floret development and seed setting (Liu C et al, 2018).

The ornithine- $\delta$-aminotransferase gene (oat) is involved in a response to stress, but its specific biological role has not been completely elucidated yet and is under discussion (Stranska J et al, 2010). It has long been believed that ornithine- $\delta$-aminotransferase is involved in proline synthesis under stress (Roosens $\mathrm{N}$ et al, 2002). There are current data, demonstrating that the OAT enzyme participates in the alternative pathway of proline metabolism in mitochondria under stress (Anwar A et al, 2018). For instance, in Brassica juncea, both the activity of OAT and proline content were enhanced with the increasing concentration of salt in the environment (Madan S et al, 1995). In Brassica napus, the expression of oat gene increased only under long-term impact of strong osmotic stress (Xue X et al, 2009). Rice 
DUBROVNA et al.

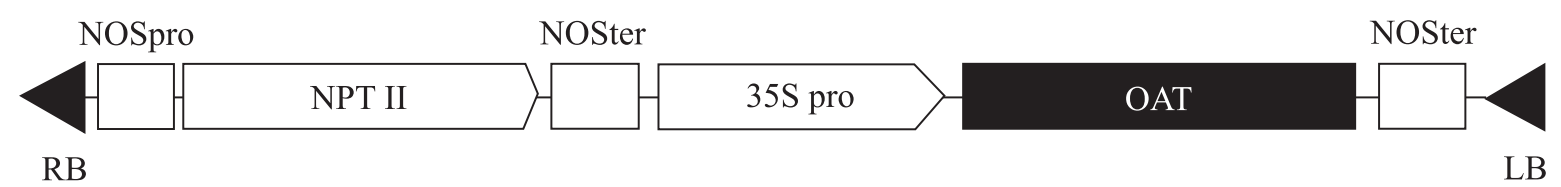

Fig. 1. The block scheme of the binary vector pBi-OAT: LB, RB - left and right borders of T-DNA; NOSpro, NOSter - promoter and terminator of nopaline synthase; $n p t$ II - gene of neomycin phosphotransferase II E. coli; 35S pro - promoter 35S of cauliflower mosaic virus (CaMV) RNA; OAT - ornithine- $\delta$-aminotransferase gene of Medicago truncatula (Gerasimova SV et al, 2010)

plants with higher expression of oat gene accumulate more proline than non-transgenic plants (Wu L et al, 2003). The overexpression of this gene enhanced the resistance of transgenic tobacco plants to drought and salinization (Roosens N et al, 2002; Gerasimova SV et al, 2010). However, the fact that both under norm and stress, mutant Arabidopsis plants, deficient in OAT, had the same proline level as the control plants (Funck D et al, 2008), may demonstrate that proline accumulation may be unrelated to OAT expression.

While introducing the exogenous oat gene into the genome of different cereals (rice, corn, sorghum) are rather successful, the research on this methodology for wheat has started rather recently and the publications are scarce. In particular, the PCR method confirmed the obtaining of transgenic spring wheat plants with the additional copy of the ornithine- $\delta$-aminotransferase gene (Honcharuk AN et al, 2015) with a frequency of $5 \%$. It was found that under the action of osmotic stress transgenic plants (T2) of winter wheat were characterized by better yield structure in comparison with control plants (Komisarenko AG et al, 2019). Furthermore, the transgenic wheat plants overexpressing gene TaOAT showed enhanced tolerance to drought stress and salt tolerance (Anwar A et al, 2020).

Our aim was to determine water deficiency tolerance of genetically modified common wheat plants (Triticum aestivum L.), containing a heterologous ornithine$\delta$-aminotransferase gene, based on the analysis of grain productivity and physiological and biochemical characteristics in transgenic and non-transgenic genotypes. The hypothesis of our research was that transgenic plants of wheat would demonstrate higher tolerance to moisture deficiency.

\section{MATERIALS AND METHODS}

The materials of the study were non-transformed plants of common spring-winter wheat, Zymoyarka variety, and three transgenic lines of the seed generation $\mathrm{T}_{2}$ (Zymoyarka 120, Zymoyarka 135, and Zymoyarka 139), obtained by Agrobacterium-mediated transformation in planta. We studied 30 plants of each transgenic line and 30 plants of the original variety. Transformation in planta was carried out by applying a drop of Agrobacterium suspension to a flower bud (Narusaka $\mathrm{M}$ et al, 2010). Ears of wheat that did not come out of the flag leaf were pre-castrated and wrapped in an individual parchment paper insulator (Zale $\mathrm{J}$ et al, 2009). Night culture of A. tumefaciens was grown on LB medium (Sambrook J et al, 1989) to achieve an optical density of $\mathrm{OD}_{600}=0.8$. Then the culture was centrifuged, the precipitate was resuspended in LB medium with the addition of $200 \mathrm{mM}$ acetosyringone (Sigma, USA) and $5 \mathrm{~g} / \mathrm{l}$ sucrose (Zale J et al, 2009).

The Agrobacterium tumefaciens AGL0 strain was used in transformation experiments. Plants were transformed with the binary vector pBi-OAT, which carries the target ornithine- $\delta$-aminotransferase gene of Medicago truncatula and selective neomycin phosphotransferase II (nptII) gene E. coli (Fig. 1). Vector design is courtesy of Corresponding Member RAS, Ph.D. Kochetov OV, Institute of Cytology and Genetics, Siberian Branch of the Russian Academy of Sciences, Novosibirsk.

Agrobacterium-mediated transformation in planta was performed in a pot experiment and the seeds were gathered at the end of vegetation period. After inoculation of 70 castrated ears, 428 grains were obtained. The obtained seed material was germinated and the fact of integration of elements of vector construction was established by PCR. As a result of the analysis, $16 \mathrm{~T}_{1}$ plants with complete incorporation of the genetic construct were identified. These plants were planted in the soil and by self-pollination obtained seed generation $\mathrm{T}_{2}$. The seeds were germinated in disposable cups with soil mixture (sand and soil $1: 2$ ). The wheat plants were grown in growth rooms under lighting 3000-4000 lx, relative humidity of $70 \%$ and a $16 / 8 \mathrm{~h}$ light/dark photoperiod cycle. The presence of target gene in 40 seedlings from $\mathrm{T}_{2}$ seeds, collected from each individual $\mathrm{T}_{1}$ plant, was analyzed. Three stable independent transgenic lines were obtained in $\mathrm{T}_{2}$ generation named as Zymoyarka 120, Zymoyarka 135, and Zymoyarka 139 which were used for further analysis. 
Confirmation of the transfer and integration of oat and npt II genes into the genomes of the studied plants was performed by polymerase chain reaction (PCR). For this purpose, the total DNA of control and selected wheat lines was isolated using the CTAB DNA extraction procedure (Stewart $\mathrm{CN}$ and Via LE, 1993). PCR was performed using the following primer pairs to the target gene: RTF forward (5'-CAGTGCCCACAATTACCATCC-3') and RTR reverse (5'-CGAACTTCTTCCC-AATCACAAGCCA-3'); to the selective $n p t$ II gene: PSGA forward (5'-AGGC-TATTCGGCTATGACTG-3') and PSGB reverse (5'-CAAGCTCTTCAGCA-ATATCACG-3'); reference gene TaTM20: RTF forward 5'-AAGGGTTGCTCCT-CTTCGCGATCTTG-3' and RTR reverse 5'-GTACATGCCAGCACCGTAT-GGATTG-3'. In order to further verify the absence of bacterial contamination in the studied wheat samples transformed by the in planta method, molecular genetic analysis was performed using specific primers to the agrobacterial virulence gene vir $\mathrm{C}$ of the following sequences: VCF forward 5'-ATCATTTGTAGCGTCGTCG-3' and VCR reverse 5'-AGCTCAAACCTGCTTC-3'.

Reaction mixtures for PCR included: $0.5 \mu \mathrm{l}$ of $10 \mu \mathrm{M}$ specific primers for the corresponding reaction, $2 \mu \mathrm{l}$ of buffer for PCR $10 \times$ Reaction Buffer B (Solis BioDyne), $2 \mu \mathrm{l}$ of $1 \mathrm{mM}$ Cresol $60 \%$ Sucrose (Solis BioDyne), $1,6 \mu$ of $25 \mathrm{mM} \mathrm{MgCl}_{2}$ (Solis BioDyne), $2 \mu 1$ of $2 \mathrm{mM}$ each deoxyribonucleotide-3-phosphate (Thermo Fisher Scientific), 0.5 units FIREPol DNA Polymerase (Solis BioDyne), 30 ng of total DNA, deionized Milli-Q water to a final volume of $20 \mu \mathrm{l}$.

PCR was performed on an amplifier Mastercycler Personal 5332 Eppendorf. PCR with primers to the oat gene was performed according to the program: initial denaturation at $94{ }^{\circ} \mathrm{C}$ for $3 \mathrm{~min} ; 30$ cycles (denaturation at $94^{\circ} \mathrm{C}-1 \mathrm{~min}$, annealing at $57^{\circ} \mathrm{C}-1$ min, elongation at $62{ }^{\circ} \mathrm{C}-1 \mathrm{~min}$ ) and final elongation at $62{ }^{\circ} \mathrm{C}$ for $8 \mathrm{~min}$. The expected amplicon size is 708 bp. Multiplex PCR was performed with primers to the wheat reference gene TaTM20 and the $n p t$ II transgene according to the following program: initial denaturation at $94^{\circ} \mathrm{C}$ for $4 \mathrm{~min} ; 8$ cycles (denaturation $94{ }^{\circ} \mathrm{C}-30 \mathrm{sec}$, annealing $68{ }^{\circ} \mathrm{C}-45 \mathrm{sec}$, elongation $72{ }^{\circ} \mathrm{C}-30 \mathrm{sec}$ ) and 25 cycles (denaturation $94{ }^{\circ} \mathrm{C}-$ $30 \mathrm{sec}$, annealing $60{ }^{\circ} \mathrm{C}-30 \mathrm{sec}$, elongation $72{ }^{\circ} \mathrm{C}-$ $30 \mathrm{sec}$ ), final elongation $72{ }^{\circ} \mathrm{C}-5 \mathrm{~min}$. The size of the expected fragments: for the $n p t I I$ gene $-700 \mathrm{bp}$, and for the TaTM20 gene- $934 \mathrm{bp}$. PCR to determine bacterial infection (Vir C gene) was performed according to the following program: initial denaturation $4 \mathrm{~min}$ at $94{ }^{\circ} \mathrm{C}, 34$ cycles - denaturation $30 \mathrm{sec}$ at $94{ }^{\circ} \mathrm{C}$, renaturation $30 \mathrm{sec}$ at $59{ }^{\circ} \mathrm{C}$, elongation $30 \mathrm{sec}$ at $72{ }^{\circ} \mathrm{C}$, final elongation $5 \mathrm{~min}$ at $72{ }^{\circ} \mathrm{C}$. Negative control - TE buffer, positive control - DNA of Agrobacterium tumefaciens strain AGLO with the genetic construct of pBi-OAT.

After the analysis, the plants were planted into $10 \mathrm{~L}$ vegetative pots, filled with soil mixture (soil : sand = $=3: 1$ ) and grown on a special growing site. In half of the pots, the original and transgenic forms (15 plants of the Zimoyarka variety and 15 plants of each transgenic line) were cultivated under optimal water supply $-70 \%$ of field capacity (FC). In other half of the pots ( 15 plants of the Zimoyarka variety and 15 plants of each transgenic line) soil humidity was decreased down to $30 \% \mathrm{FC}$ at flag leaf sheath opening (GS 47) (Zadoks JC et al, 1974), by stopping the irrigation and next everyday controlling of pots weight during 7 days. Soil humidity was controlled by gravimetric method (Gilev VYu, 2012). After drought, the plants of variants $30 \% \mathrm{FC}$ were watered along with the control under full ripeness.

Biochemical traits and photosynthetic pigments content were determined on the $7^{\text {th }}$ day since the beginning of drought. The activity of ornithine- $\delta$-aminotransferase (OAT) in the leaves was estimated according to (Madan $\mathrm{S}$ et al, 1995) and calculated as the amount of the enzyme, necessary to obtain $1 \mathrm{nmol}$ of P5C per minute (1U), calculated per $1 \mathrm{mg}$ of protein. Free proline content in the leaves was determined by method, based on the formation of a stained product of interaction between L-proline and ninhydrin reagent (Bates LS et al, 1973). Enzyme activity and proline content were determined in 5 biological and 3 analytical repeats.

Total chlorophyll and carotenoid content was determined by non-maceration method of extracting pigments from leaf using dimethyl sulfoxide (DMSO) by the method of A.P. Wellburn (Wellburn AP, 1994). The average sample was formed from five flag leaves of main and later shoots. For this, all leaves were finely cut. For the analytical pigment content estimation from the total sample of cut leaves $100 \mathrm{mg}$ leaf material was extracted in $10 \mathrm{ml}$ DMSO in triplicate. Then the tubes were placed in a water bath (water temperature $60{ }^{\circ} \mathrm{C}$ ) for $4 \mathrm{~h}$. After cooling to room temperature, $0.5 \mathrm{~mL}$ of obtained extracts was diluted with $4.5 \mathrm{~mL}$ of DMSO. The optic density of this solution was determined using a spectrophotometer (Specord 200, AnalyticJena, Germany), at a wavelength of 480, 649, and $665 \mathrm{~nm}$. 

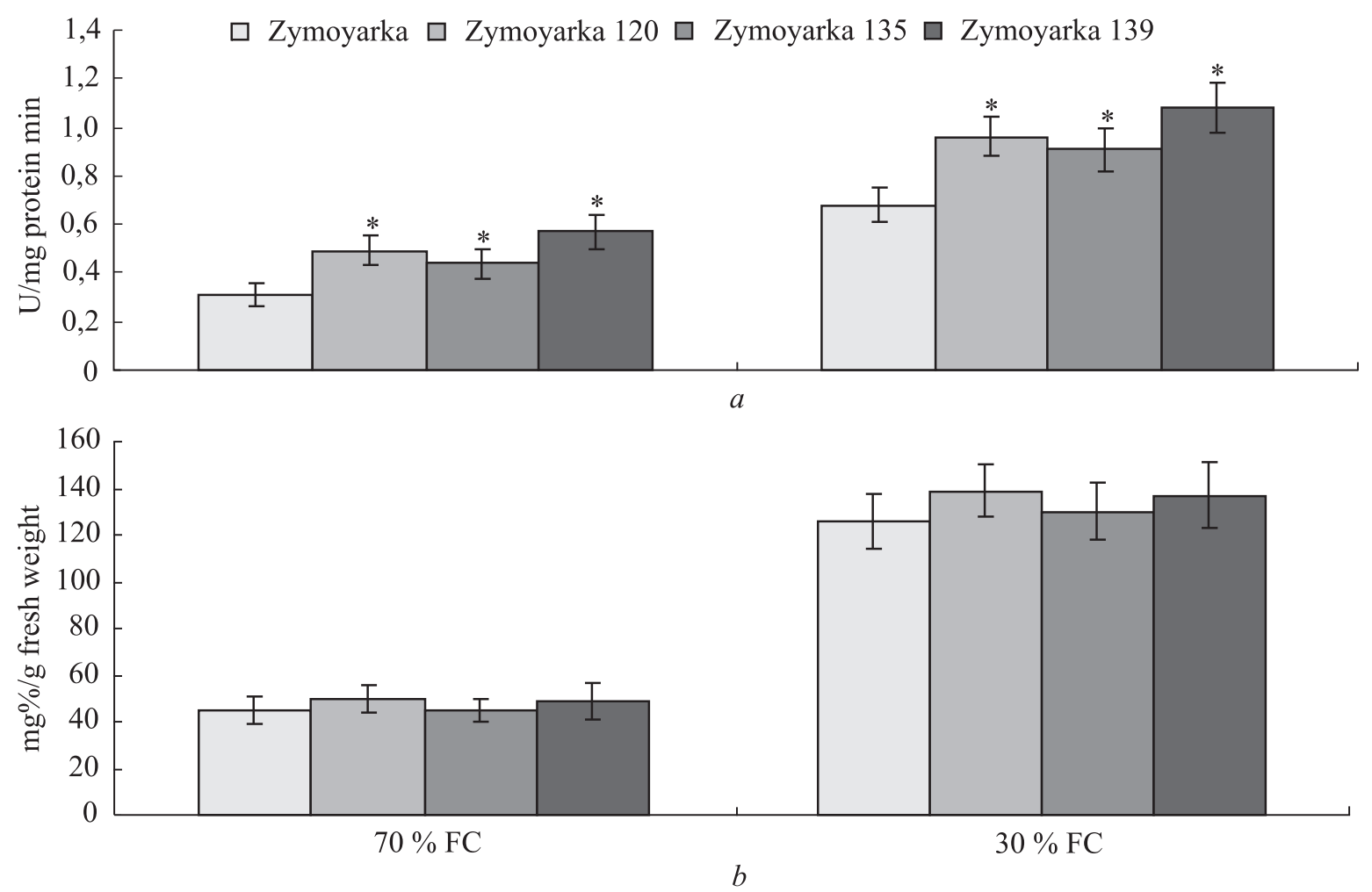

Fig. 2. The activity of ornithine- $\delta$-aminotransferase enzyme $(a)$ and the content of free L-proline $(b)$ in the plants of original variety Zymoyarka and transgenic lines under optimal water supply (70 \% of FC) and drought (30 \% FC). Note: $\mathrm{m} \pm \mathrm{SE},{ }^{*}-$ the difference between transgenic lines and the plants of original variety is significant at $\mathrm{p}<0.05$

The calculation of the pigment content per $1 \mathrm{~g}$ of dry matter was conducted with the consideration of all the dilutions and the weight of leaves.

The indices of grain productivity (grain weight per plant, number of grains per ear and plant, thousand grain weights) were determined at full ripeness, as well as the number of productive shoots, length, and root dry weight of control and genetically modified plants. The number of plants in each variant was 10 .

The statistical processing of the obtained data was conducted using ANOVA and the Tukey HSD Test with the average values. The results were presented as mean values and standard error $(m \pm S E)$. The difference between the data was considered reliable, if $p \leq$ $\leq 0.05$. Calculations were done using computer software STATISTIX8.

\section{RESULTS}

To estimate, in which way the introduced construction influences the expression of oat gene, we compared the activity of ornithine- $\delta$-aminotransferase enzyme in transformed plants and the original plants of Zymoyarka variety in the control and under drought. It was established that in the variant, where soil moisture was maintained at the level of $70 \% \mathrm{FC}$, the activity of OAT in the original plants was $0.31 \pm$ $\pm 0.05 \mathrm{nmol} \mathrm{P} 5 \mathrm{C} / \mathrm{min}$.*mg of protein, and in the transgenic plants it was 1.6 times higher on average $-0.50 \pm$ $\pm 0.07 \mathrm{nmol} \mathrm{P} 5 \mathrm{C} / \mathrm{min}$. ${ }^{*} \mathrm{mg}$ of protein (Fig. 2, a). On the $7^{\text {th }}$ day of drought, the activity of OAT in non-transgenic plants of the variety Zymoyarka $(0.68 \pm 0.07 \mathrm{nmol}$ $\mathrm{P} 5 \mathrm{~K} / \mathrm{min}$. ${ }^{*} \mathrm{mg}$ protein), and in transgenic plants $(0.98 \pm$ $\pm 0.09 \mathrm{nmol} \mathrm{P} 5 \mathrm{~K} / \mathrm{min}$. ${ }^{*} \mathrm{mg}$ protein) increases by about 2 times compared to plants that grow at soil moisture at the level of $70 \%$ of FC. In transgenic forms under drought conditions, the enzyme activity was also higher (on average 1.5 times) compared to non-transgenic plants that grew under stress conditions. Therefore, in transgenic plants, compared with non-transgenic, an increase in OAT activity was observed, both with optimal moisture supply and its deficiency, which is obviously due to the expression of the introduced gene.

Under drought the level of free L-proline in the original variety increased, as compared with $70 \% \mathrm{FC}$, from $45 \pm 6$ to $126 \pm 12 \mathrm{mg} \% / \mathrm{g}$ fresh weight was found (Fig. 2,b). The content of free L-proline in the plants of transgenic lines at $30 \% \mathrm{FC}$ was higher, than under optimal water supply, respectively - 45-50 and 130$139 \mathrm{mg} \% / \mathrm{g}$ fresh weight was found (Fig. 2, b). Thus, 

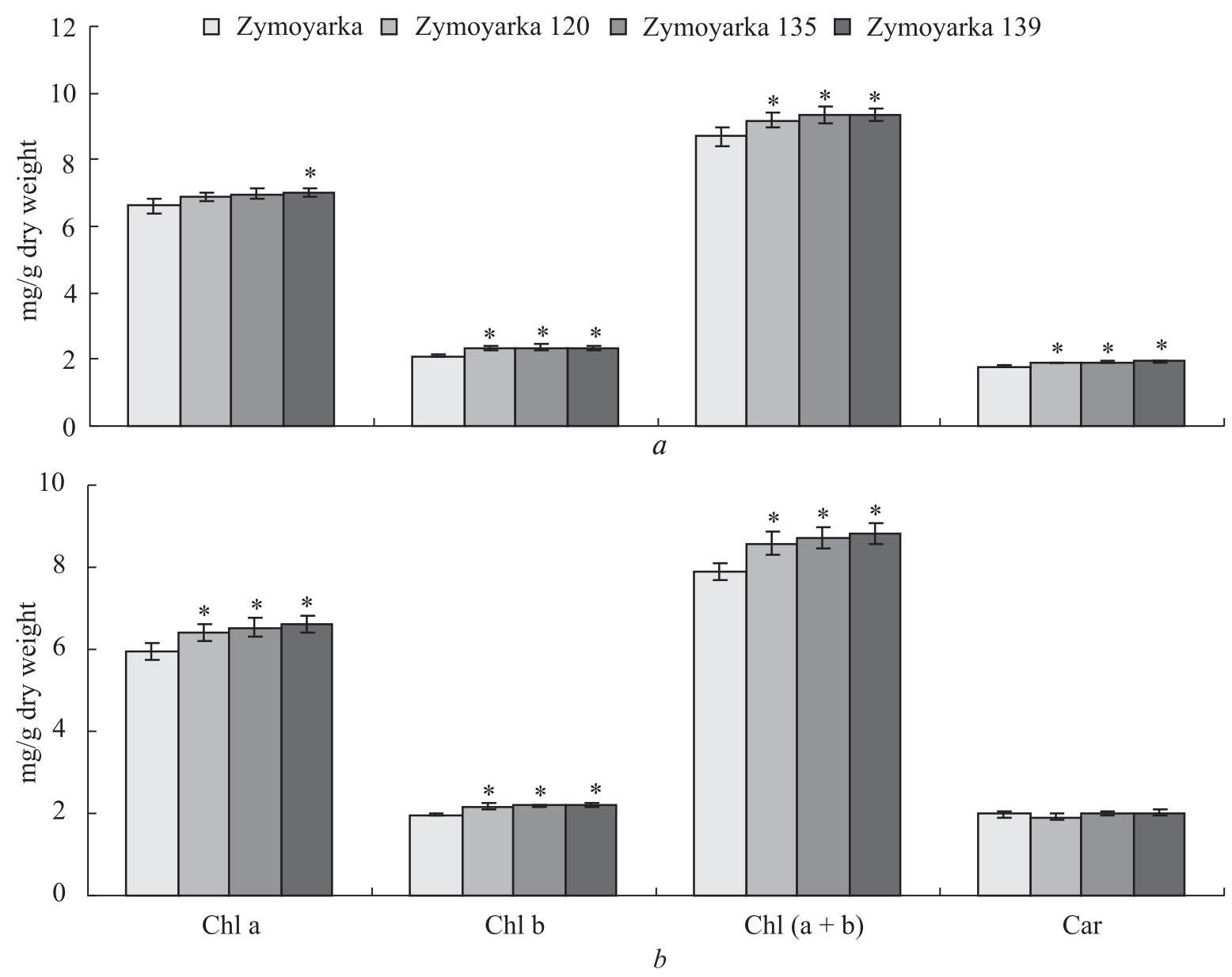

Fig. 3. The photosynthetic pigments content in flag leaves of the original variety (Zymoyarka) and its transgenic lines under optimal water supply $(a)$ and drought $(b)$. Note: $\mathrm{m} \pm \mathrm{SE},{ }^{*}-$ the difference between transgenic lines and the plants of original variety is significant at $\mathrm{p}<0.05$

the free L-proline content both in the original and transgenic plants increased almost three times, as compared to the corresponding control variants. However, the proline content did not differ considerably between genetically modified lines and the original variety in the variants with 70 or $30 \%$ of FC. So, the free L-proline content does not change considerably with the increase in OAT activity, as compared to the initial genotype. We found that the introduction of the genetic construct, enhancing the expression of oat gene, does not lead to a considerable change in the level of free L-proline in plant leaves under norm or drought.

Comparative analysis of the content and ratio of photosynthetic pigments in transgenic lines and the original genotype was carried out under optimal growing conditions and under drought conditions. Under optimal water supply, the chlorophyll $a$ content in flag leaves was higher, as compared to the original genotype, only in the transgenic Zymoyarka line 139 (resp., $7.02 \pm 0.13$ and $6.61 \pm 0.24 \mathrm{mg} / \mathrm{g}$ dry weight) (Fig. 3, a). While under drought, it was higher in all the lines: $5.93 \pm$ \pm 0.21 and $6.40-6.61 \mathrm{mg} / \mathrm{g}$ dry weight respectively (Fig. 3, $b$ ). The content of chlorophyll $b$ in the leaves of non-transformed plants was lower as compared to the plants of transgenic lines both in the control variant $(2.10 \pm 0.04$ and $2.32-2.36 \mathrm{mg}$ g dry weight, respectively), and under drought $(1.97 \pm 0.02$ and 2.17 $2.20 \mathrm{mg} / \mathrm{g}$ dry weight, respectively) (Fig. 3). On average, in both variants its content in the transgenic lines exceeded the corresponding values of the original variety by $10-12 \%$.

The total chlorophylls content $(a+b)$ in flag leaves of the transgenic plants was higher $(9.19-9.34 \mathrm{mg} / \mathrm{g}$ dry weight) as compared to the non-transformed plants $(8.71 \pm 0.28)$ under optimal water supply (Fig. 3,a). and under drought $(8.57-8.81$ and $7.90 \pm 0.23 \mathrm{mg} / \mathrm{g}$ dry weight, respectively) (Fig. 3, b). The rise of the total chlorophyll content in the transgenic lines as compared to the non-transformed plants was smaller 
in the control that under drought (by 5-7\% and by $8-11 \%$, respectively). The total carotenoid content in flag leaves of transgenic lines exceeded their content in the non-transformed plants only in the control variant $(1.89-1.95$ and $1.79 \pm 0.04 \mathrm{mg} / \mathrm{g}$ dry weight, respectively) (Fig. 3,a), under drought the difference between them was insignificant (Fig. 3, b).

Under drought, the chlorophyll $a$ content in flag leaves of both the original Zymoyarka variety and the transgenic genotypes decreased to $92 \%$ and $93-$ $94 \%$ from the corresponding control variant (Table 1). There was also a similar decrease in the content of chlorophyll $b$ both in the transformed and non-transformed plants - up to $92-95 \%$ from the control. The total chlorophyll content in flag leaves of the transgenic lines and non-transformed plants, compared their values in the control, also changed at close range: up to $93-94 \%$ and to $91 \%$. Under drought, the total carotenoid content increased significantly (by 11 $\%)$ in the plants of the original variety only, for trans- genic lines the difference with $70 \% \mathrm{FC}$ variant was insignificant.

In the control variant, the chlorophyll $a / b$ ratio in flag leaves of the original variety was higher than in transgenic plants, whereas under drought there was no difference between them (Table 2). This ratio was higher in the leaves of the original variety at $70 \% \mathrm{FC}$ than under drought (respectively, $3.14 \pm 0.05$ and $3.02 \pm 0.07$ ). No significant difference was observed for transgenic plants. Non-transformed plants and transgenic genotypes at $70 \%$ FC did not differ by the Car/Chl ratio, and under drought this ratio was lower $(0.22-0.23)$ in the modified plants than in Zymoyarka variety $(0.25 \pm$ 0.01). Under drought, the $\mathrm{Car} / \mathrm{Chl}$ ratio was higher in all forms of plants than in the corresponding variants at $70 \% \mathrm{FC}$.

Therefore, the transgenic plants were characterized by a higher total chlorophyll content $(a+b)$ in flag leaves under both water supply regimes $(9.19-9.34 \mathrm{mg} / \mathrm{g}$ dry weight at $70 \% \mathrm{FC}$ and $8.57-8.81 \mathrm{mg} / \mathrm{g}$ dry weight at

Table 1. The influence of drought on the photosynthetic pigments content in flag leaves of the original Zymoyarka variety and transgenic lines, $\%$ to the corresponding variant at $70 \% \mathrm{FC}$

\begin{tabular}{l|c|c|c|c}
\hline \multirow{2}{*}{ Genotype } & \multicolumn{4}{|c}{ Content, \% } \\
\cline { 2 - 5 } & Chlorophyll $a$ & Chlorophyll $b$ & $\begin{array}{c}\text { Total chlorophylls } \\
\text { content }(a+b)\end{array}$ & Carotenoids \\
\hline Zymoyarka variety & $92 *$ & $94 *$ & $91 *$ & $111^{*}$ \\
Zymoyarka 120 & $93 *$ & 93 & $93 *$ & 101 \\
Zymoyarka 135 & $94 *$ & $92 *$ & $94 *$ & 105 \\
Zymoyarka 139 & $94 *$ & $95 *$ & $94 *$ & 104 \\
\hline
\end{tabular}

Note: * the difference with the plants of the corresponding variant at $70 \% \mathrm{FC}$ is reliable at $\mathrm{p} \leq 0.05$.

Table 2. The chlorophyll $a / b$ and carotenoid/total chlorophyll ratios in flag leaves of the original Zymoyarka variety and the transgenic lines

\begin{tabular}{c|l|c|c}
\hline \multirow{2}{*}{ Variant } & \multicolumn{2}{|c}{ Renotype } & \multicolumn{2}{|c}{ Ratio of } \\
\cline { 2 - 3 } & & chlorophyll $a / b$ & Car/Chl $(a+b)$ \\
\hline \multirow{2}{*}{$70 \% \mathrm{FC}$} & Zymoyarka variety & $3.14 \pm 0.05$ & $0.21 \pm 0.01$ \\
& Zymoyarka 120 & $2.96 \pm 0.07 *$ & $0.21 \pm 0.01$ \\
& Zymoyarka 135 & $2.96 \pm 0.05^{*}$ & $0.21 \pm 0.01$ \\
& Zymoyarka 139 & $3.03 \pm 0.02 *$ & $0.21 \pm 0.01$ \\
& Zymoyarka variety & $3.02 \pm 0.07 \#$ & $0.25 \pm 0.01 \#$ \\
& Zymoyarka 120 & $2.95 \pm 0.02$ & $0.22 \pm 0.01^{*} \#$ \\
& Zymoyarka 135 & $2.99 \pm 0.04$ & $0.23 \pm 0.01^{* \#}$ \\
& Zymoyarka 139 & $3.01 \pm 0.05$ & $0.23 \pm 0.01^{* \#}$ \\
\hline
\end{tabular}

Note. The difference is significant at $\mathrm{p} \leq 0.05:{ }^{*}$ - as compared to the original variety, $\#-$ as compared to the corresponding control. 
$30 \%$ FC), than original variety $(8.71 \pm 0.28$ and $7.90 \pm$ $\pm 0.23 \mathrm{mg} / \mathrm{g}$ dry weight, respectively). The transgenic lines were higher in total carotenoid content (1.89$1.95 \mathrm{mg} / \mathrm{g}$ dry weight), than variety Zymoyarka (1.79 \pm \pm 0.04 ) only under optimal water supply. Under drought, the chlorophyll a/b ratio in flag leaves of transgenic genotypes did not differ from its values in the original variety, whereas the $\mathrm{Car} / \mathrm{Chl}$ ratio in them was $8-12 \%$ lower.

The comparative analysis of growth parameters for the transgenic plants at full ripeness showed that they were higher than the plants of the original variety: in the control variant - by $8 \mathrm{~cm}$ on average, under drought by $10 \mathrm{~cm}$ (Table 3 ).

By root length, the genetically modified plants in the variant with optimal water supply differed from the original variety with an increase in length of 3.4$3.9 \mathrm{~cm}$, under drought by $4.2-4.6 \mathrm{~cm}$. Drought shortened the root length of the original variety by $18 \%$, that of the lines by $3-6 \%$.

By the number and weight of grains from the spike of the main shoot, the difference between the transgenic lines and the original variety was insignificant in both variants (Table 4). Under drought, the grain weight from the spike of the main shoot in the original variety, as well as in the lines, no significant differences from $70 \% \mathrm{FC}$, too.

In the transgenic lines, the number and weight of grains per plant were, on average, considerably higher than in the original variety: by 20 and $18 \%$ in $70 \% \mathrm{FC}$, and by 26 and $29 \%$ in $30 \% \mathrm{FC}$, respectively (Table 5). Under drought, the number and weight of grains per plant of the original variety decreased by 17 and $28 \%$, respectively, and in all modified plants, on average, by 12 and $17 \%$.

The dry root weight of whole plants of the transgenic lines exceeded the original variety both under optimal water supply (by 23-27\%), and under drought (by 37-44\%) (Table 6). In drought-affected plants of the original variety the root weight decreased by $29 \%$ in the original variety and by $11-15 \%$ in the lines.

Number of productive shoots of the transgenic plants both at $70 \% \mathrm{FC}(3.0-3.4$ item), and at $30 \% \mathrm{FC}(2.7-$

Table 3. The growth parameters of the main shoot of the original variety Zymoyarka and the transformed lines under optimal water supply (70 \% FC) and drought (30\% FC) $(\mathrm{M} \pm \mathrm{m}, \mathrm{n}=10$ plants)

\begin{tabular}{|c|c|c|c|}
\hline \multirow{2}{*}{ Genotype } & \multirow{2}{*}{ Height of plants, $\mathrm{cm}$} & \multicolumn{2}{|c|}{ Length, $\mathrm{cm}$} \\
\hline & & of spike & of roots \\
\hline \multicolumn{4}{|c|}{ Sufficient water } \\
\hline Zymoyarka control & $88.2 \pm 3.0$ & $8.4 \pm 0.6$ & $8.5 \pm 0.4$ \\
\hline Zymoyarka 120 & $96.4 \pm 4.0^{*}$ & $8.9 \pm 0.8$ & $12.4 \pm 1.3^{*}$ \\
\hline Zymoyarka 135 & $95.9 \pm 3.7^{*}$ & $9.2 \pm 0.9$ & $11.9 \pm 1.0^{*}$ \\
\hline Zymoyarka 139 & $96.1 \pm 4.2 *$ & $9.3 \pm 0.9$ & $12.1 \pm 1.4^{*}$ \\
\hline \multicolumn{4}{|c|}{ Drought } \\
\hline Zymoyarka control & $72.3 \pm 3.7 \#$ & $6.7 \pm 0.6 \#$ & $7.2 \pm 0.5 \#$ \\
\hline Zymoyarka 120 & $81.4 \pm 3.5^{* \#}$ & $8.4 \pm 0.7$ & $11.7 \pm 1.1^{*}$ \\
\hline Zymoyarka 135 & $82.2 \pm 2.8^{* \#}$ & $8.8 \pm 0.8$ & $11.4 \pm 1.4^{*}$ \\
\hline Zymoyarka 139 & $82.9 \pm 4.9 * \#$ & $8.6 \pm 0.6$ & $11.8 \pm 1.0^{*}$ \\
\hline
\end{tabular}

Note: the difference is significant at $\mathrm{p} \leq 0.05: *$ - as compared to the original variety, $\#$ - as compared to the corresponding control.

Table 4. The yield components of main shoot of variety Zymoyarka and transformed lines under optimal water supply and drought ( $\mathrm{M} \pm \mathrm{m}, \mathrm{n}=10$ plants)

\begin{tabular}{l|c|c|c|c}
\hline \multirow{2}{*}{ Genotype } & \multicolumn{2}{|c|}{ Number of grains, it } & \multicolumn{2}{c}{ Grain weight, g } \\
\cline { 2 - 4 } & $70 \% \mathrm{FC}$ & $30 \% \mathrm{FC}$ & $70 \% \mathrm{FC}$ & $30 \% \mathrm{FC}$ \\
\hline Zymoyarka control & $39.6 \pm 2.4$ & $35.2 \pm 2.1$ & $1.17 \pm 0.09$ & $0.97 \pm 0.08$ \# \\
Zymoyarka 120 & $42.4 \pm 3.1$ & $38.8 \pm 2.8$ & $1.23 \pm 0.07$ & $1.12 \pm 0.07$ \\
Zymoyarka 135 & $40.2 \pm 3.1$ & $37.0 \pm 3.0$ & $1.20 \pm 0.08$ & $1.05 \pm 0.08$ \\
Zymoyarka 139 & $43.1 \pm 3.9$ & $39.3 \pm 2.4$ & $1.24 \pm 0.08$ & $1.13 \pm 0.07$ \\
\hline
\end{tabular}




\section{DUBROVNA et al.}

$3.1)$ exceeded the original variety ( 2.5 and 2.2 shoots, rspectively) (Table 6). Thus, the whole plants of transgenic lines differed from the variety by increased root weight and number of productive shoots both under optimal water supply and drought.

\section{DISSCUSION}

Drought changes the physiological, morphological, biochemical and molecular characteristics of the plant (Kapoor D et al, 2020). At the molecular level, drought-induced stress induces an expression/repression of genes that affect the metabolism of a number of biochemical substances involved in dehydration processes, including osmotic regulation (Yang $\mathrm{S}$ et al, 2010; Budak H et al, 2015). Genetic-engineering technologies that target at the increase of plant tolerance to osmotic stress associated with changes in the level of gene expression and catabolism of free L-proline are of considerable interest (Gerasimova SV et al, 2010; Khan MS, 2015; Anwar, 2020). Numerous data describe the unique properties of this amino acid, which has a complex impact on numer- ous vital functions of organisms under normal conditions and stress (Szabados L and Savoure A, 2010; Kaur G, 2015).

Proline in plants can be synthesized in two ways from glutamate or ornithine. Under abiotic stress, its biosynthesis is mainly from glutamate and the most important enzyme is P5CS (Szabados L and Savoure A, 2010; Liang X et al, 2013). In transgenic plants increased expression of the P5CS gene is positively correlated with the accumulation of free proline and increased levels of resistance to osmotic stress (Guerzoni JTS, 2014; Guan C et al, 2019). The accumulation of proline is also regulated by the level of expression of the proline dehydrogenase gene. Under stress, expression of the proline dehydrogenase is suppressed and P5CS transcription is induced (Hein et al, 2016; Anwar et al, 2018). In our studies of transgenic common wheat plants, containing a double-stranded RNA suppressor of the proline dehydrogenase gene, it was also shown that partial suppression of this gene leads to decreased enzyme activity and increased free proline content and

Table 5. The yield components of whole plant of variety Zymoyarka and transformed lines under optimal water supply and drought $(\mathrm{M} \pm \mathrm{m}, \mathrm{n}=10$ plants $)$

\begin{tabular}{l|r|c|c|c|c|c|c|c}
\hline \multirow{2}{*}{ Genotype } & \multicolumn{2}{|c|}{ Number of grains, it } & \multicolumn{2}{c|}{$\%$ from Zymoyarka } & \multicolumn{2}{c|}{ Grain weight, $\mathrm{g}$} & \multicolumn{2}{c}{$\%$ from Zymoyarka } \\
\cline { 2 - 9 } & $70 \% \mathrm{FC}$ & $30 \% \mathrm{FC}$ & $70 \% \mathrm{FC}$ & $30 \% \mathrm{FC}$ & $70 \% \mathrm{FC}$ & $30 \% \mathrm{FC}$ & $70 \% \mathrm{FC}$ & $30 \% \mathrm{FC}$ \\
\hline Zymoyarka con- & $87.7 \pm 2.7$ & $74.7 \pm 3.1^{\#}$ & 100 & 100 & $2.24 \pm 0.10$ & $1.75 \pm 0.09 \#$ & 100 & 100 \\
trol & & & & & & & & \\
Zymoyarka 120 & $106.4 \pm 3.3^{*}$ & $96.5 \pm 4.8^{*}$ & 121 & 129 & $2.63 \pm 0.13^{*}$ & $2.34 \pm 0.11^{* \#}$ & 117 & 134 \\
Zymoyarka 135 & $98.9 \pm 4.9^{*}$ & $89.1 \pm 4.5^{* \#}$ & 113 & 119 & $2.54 \pm 0.11^{*}$ & $2.15 \pm 0.13^{* \#}$ & 113 & 123 \\
Zymoyarka 139 & $110.4 \pm 4.8^{*}$ & $95.7 \pm 4.6^{*}$ & 126 & 128 & $2.75 \pm 0.12^{*}$ & $2.29 \pm 0.13^{* \#}$ & 123 & 121 \\
\hline
\end{tabular}

Note. The difference is significant at $\mathrm{p} \leq 0.05:{ }^{*}$ - as compared to the original variety, \#- as compared to the $70 \% \mathrm{FC}$.

Table 6. The root weight of whole plant and number of productive shoots of variety Zymoyarka and transformed lines under optimal water supply and drought $(\mathrm{M} \pm \mathrm{m}, \mathrm{n}=10$ plants $)$

\begin{tabular}{|c|c|c|c|c|c|c|c|c|}
\hline \multirow{2}{*}{ Genotype } & \multicolumn{2}{|c|}{ Root weight, $g$} & \multicolumn{2}{|c|}{$\%$ from Zymoyarka } & \multicolumn{2}{|c|}{$\begin{array}{l}\text { Number of productive } \\
\text { shoots, it. }\end{array}$} & \multicolumn{2}{|c|}{$\%$ from Zymoyarka } \\
\hline & $70 \% \mathrm{FC}$ & $30 \% \mathrm{FC}$ & $70 \% \mathrm{FC}$ & $30 \% \mathrm{FC}$ & $70 \% \mathrm{FC}$ & $30 \% \mathrm{FC}$ & $70 \% \mathrm{FC}$ & $30 \% \mathrm{FC}$ \\
\hline $\begin{array}{l}\text { Zymoyarka con- } \\
\text { trol }\end{array}$ & $1.62 \pm 0.14$ & $1.26 \pm 0.07 \#$ & 100 & 100 & $2.5 \pm 0.1$ & $2.2 \pm 0.2 \#$ & 100 & 100 \\
\hline Zymoyarka 120 & $2.06 \pm 0.17^{*}$ & $1.80 \pm 0.11^{*}$ & 127 & 143 & $3.2 \pm 0.2 *$ & $3.0 \pm 0.2 *$ & 128 & 136 \\
\hline Zymoyarka 135 & $1.99 \pm 0.13^{*}$ & $1.73 \pm 0.15^{*}$ & 123 & 137 & $3.0 \pm 0.2 *$ & $2.7 \pm 0.2 *$ & 120 & 123 \\
\hline Zymoyarka 139 & $2.01 \pm 0.16^{*}$ & $1.81 \pm 0.10^{*}$ & 124 & 144 & $3.4 \pm 0.2 *$ & $3.1 \pm 0.2 *$ & 136 & 141 \\
\hline
\end{tabular}

Note: the difference is significant at $\mathrm{p} \leq 0.05:{ }^{*}$ - as compared to the original variety, \#- as compared to the $70 \% \mathrm{FC}$. 
increases the resistance of wheat plants to water deficiency (Dubrovna OV et al, 2020).

The glutamate pathway of proline biosynthesis is well known in plants, whereas the pathway of ornithine is not yet clearly established. The mechanism of proline accumulation via OAT under a broad spectrum of stress conditions is not fully understood (Sharma $\mathrm{S}$ and Verslues PE, 2010; Gerasimova SV et al, 2011; Anwar A et al, 2018, 2020). It has also been determined that OAT regulates ornithine degradation and is associated with the nitrogen recirculation system (Funck et al, 2008). In particular, the recently discovered interaction of oat genes of hexaploid wheat lines with genes associated with proline biosynthesis and arginine catabolism enzymes, confirms that they are involved in proline synthesis and nitrogen remobilization (Anwar A et al, 2020).

Several studies have found a positive correlation between OAT activity and proline synthesis under stressful conditions. Increased AtOAT gene expression and activity provide an additional pathway for proline biosynthesis in Nicotiana plumbaginifolia plants (Roosens $\mathrm{NH}$ et al, 2002). Expression of AtOAT in rice plants increased the proline content by 5 to 15 times compared to wild-type plants under salinity and drought (Wu L et al, 2003). It was also found that overexpression of OsOAT increases the osmotolerance of transgenic rice (You J et al, 2012). Moreover, it was established that exogenous use of ornithine increases the activity of OAT and the accumulation of proline in cashew plants under salt stress (Da Rocha IM et al, 2012). It has been reported that under stress in plants, in addition to the glutamate pathway, proline can also be synthesized from ornithine through OAT (Rizzi Y et al, 2015). Transgenic wheat plants with TaOAT overexpression showed increased drought resistance due to increased proline content (Anwar A et al, 2020).

However, there are studies in which it is shown that the change in OAT activity did not affect of the proline content, for example in Nicotiana tabacum transgenic plants, neither under normal conditions nor under osmotic stress caused by salinity (Gerasimova SV et al, 2010). In Arabidopsis plants, the level of free proline increased under salt stress, but OAT activity remained unchanged (Roosens NH et al, 1998). In $V$. aconitifolia plants, the level of OAT decreased in response to salt stress, but increased with excessive nitrogen intake (Delauney AJ et al, 1993). It was concluded that OAT is involved in the catabolism of arginine and does not affect the accumulation of proline caused by stress (Funck D et al, 2008). So the role of the OAT enzyme in stress-induced proline accumulation in plants is under discussion and needs to be clarified, and additional research to confirm its role during abiotic stress is necessary.

Our studies have shown that the introduction of a genetic construct that increases the expression of the oat gene does not lead to a significant change in the level of free L-proline in the leaves of wheat plants, neither under optimal conditions, nor under drought. In the genetically modified lines, the content of proline did not differ significantly from the original variety plants, neither at $70 \% \mathrm{FC}$, nor at $30 \% \mathrm{FC}$. These data support the hypothesis that OAT does not directly affect the accumulation of proline caused by stress (Funck D et al, 2008; Gerasimova et al, 2010). We found, however, that transgenic plants grow better in conditions of water deficit, which confirms a certain role of OAT in the acquisition of stress resistance.

Chlorophyll content in the leaves can reflect plant drought tolerance (Allahverdiyev et al, 2015). Many studies demonstrate that under drought the content and ratio of photosynthetic pigment forms in drought-resistant genotypes remains higher as compared to nonresistant ones (Morgun VV et al, 2019; Ahmed HGMD et al, 2020; le Roux ML et al, 2020). There is still few information on the difference in chlorophyll content between the original type and transgenic wheat plants under drought. It was established that wild-type Tugela DN wheat plants showed a greater loss in chlorophyll ( $\pm 50 \%$ ) within 7 days after water deficit induction (at late booting stage), and also much sooner than the mutant RYNO3936 plants with superior characteristics regarding tolerance to water deficit (le Roux ML et al, 2020). In other plant species a higher chlorophyll content was confirmed in transgenic plants containing ornithine genes. For example, two mODC transgenic lines, containing a transgenic mouse ornithine decarboxylase gene, as compared to the wild type of Arabidopsis thaliana, had significantly higher chlorophyll $a$ and chlorophyll $b$ content per mg protein basis (Majumdar $\mathrm{R}$ et al, 2016). Three transgenic lines of Arabidopsis plants overexpressing the first arginine pathway enzyme gene (SlNAGS1), with increased tolerance to drought and salt stress were higher in chlorophyll content than the wildtype, too (Kalamaki MS et al, 2009). Our findings of an increase in chlorophyll content (8-11\%) under drought conditions in the leaves of transgenic lines with an additional copy of the oat gene as compared with non-transgenic cv Zimoyarka plants, point also to their increased tolerance to water deficit. 
The genetically modified plants obtained by us were characterized by a better developed root system (dry root weight of the transgenic plants exceeded the original variety both in the control by $23-27 \%$, and under drought by $37-44 \%$ ) and and by increase of the number of productive stems (on average, 3.3 compared to 2.5 in non-transgenic plants at $70 \% \mathrm{FC}$ and 2.9 vs 2.2 at $30 \%$ FC). Transgenic Arabidopsis plants, with the tomato N-acetyl-L-glutamate synthase (SINAGS1) gene, accumulated more ornithine and showed increased tolerance to salt stress and drought (Kalamaki MS et al, 2009). Tobacco transformants containing the oat gene, showing an increased tolerance to salt stress, were characterized by a higher fresh weight of shoots and roots compared to the non-transgenic control (Gerasimova SV et al, 2010). Greater root weight and more productive stems under drought stress may be due to the accumulation of ornithine, which is the intermediate compound in the arginine biosynthesis, where the pathway deviates to the formation of compounds such as proline and polyamines, which are known to perform osmoprotective functions (Kalamaki MS et al, 2009).

Studies carried out on 10 wheat genotypes under drought-stressed and well-watered conductions shown that drought tolerance is associated with the length of the longest root (Becker SR et al, 2016). The dry weight of the root at depth is considered the main physiological indicator of adaptation to drought (Lopes MS and Reynolds MP, 2010). This is due to the fact that genotypes that have longer and more branched roots can make better use of water and nutrients (Wasson AP et al, 2012). Because drought causes an imbalance in the plant's mineral nutrition, secondary negative effects can be observed (Ahanger MA et al, 2016). Insufficient moisture supply impairs the transport of mineral nutrients from the root to the aboveground organs, due to reduced transpiration intensity and dysfunction of membrane transporters (Ahanger MA et al, 2016).

Thus, the analysis of genetically modified common wheat plants $\mathrm{cv}$. Zymoyarka, containing the heterologous alfalfa ornithine- $\delta$-aminotransferase gene, by yield structure elements, morphometric parameters and photosynthetic pigment content, showed their better tolerance to soil drought as compared to non-transgenic plants. We explain the improvement of grain productivity of the whole plant in transgenic wheat lines with an additional copy of oat gene by the fact that they have a better developed root system (dry root weight of the transgenic plants exceeded the original variety both in the control by $23-27 \%$, and under drought by $37-$ $44 \%$ ) and a higher (on average for 3 lines - 3.3 compared to 2.5 in non-transgenic plants at $70 \% \mathrm{FC}$ and 2.9 vs 2.2 at $30 \%$ FC) number of productive shoots than in the original variety both under optimal and insufficient water supply.

The increase in the chlorophyll content by $8-11 \%$ in the leaves of transgenic lines with an additional copy of the oat gene under drought conditions as compared with non-transgenic plants of the Zimoyarka variety, which we established, may also indicate their better tolerance to water deficit.

\section{CONCLUSIONS}

The analysis of genetically modified common wheat plants cv. Zymoyarka, containing the heterologous alfalfa ornithine- $\delta$-aminotransferase gene, by yield structure elements, morphometric parameters and photosynthetic pigment content showed their better tolerance to soil drought as compared to non-transgenic plants. Transgenic plants are characterized by the formation of a higher (on average for 3 lines - 3.3 compared to 2.5 in non-transgenic plants at $70 \% \mathrm{FC}$ and $2.9 \mathrm{vs}$ 2.2 at $30 \%$ FC) number of productive shoots than in the original variety both under optimal and insufficient water supply. They were also characterized by a more developed root system (dry root weight of the transgenic plants exceeded the original variety both in the control by $23-27 \%$, and under drought by $37-$ $44 \%)$. The increase in the total chlorophyll $(a+b)$ content in flag leaves of transgenic plants was established under conditions of both optimal water supply and drought, as compared with the original genotype (increase by $5-7 \%$ and $8-11 \%$, respectively) may also indicate their better tolerance to water deficit. The formation of a larger number of productive shoots and a more developed root system positively influence the yield of genetically modified plants and increase their ability to grow and development in conditions of water scarcity.

Adherence to ethical principles. All experiments described in this paper were non animal based.

Conflict of interest. Authors declare no conflict of interest.

Financing. This study was financed by Cabinet of Ministers of Ukraine within the framework of the project of "Supporting the development of priority directions in scientific studies" (program budget classification code 6541230). 


\section{Толерантність до водного дефіциту генетично-модифікованих рослин пшениці м'якої сорту Зимоярка з гетерологічним геном орнітин- $\delta$-амінотрансферази}

О. В. Дубровна, Г. О. Прядкіна, С. І. Михальська, А. Г. Комісаренко

Інститут фізіології рослин і генетики НАН України, вул. Васильківська, 31/17, Київ, Україна, 03022

E-mail: dubrovny@ukr.net*,galpryadk@gmail.com, mykhalskasvitlana@gmail.com, allakomisarenko2017@gmail.com

Мета. Визначити толерантність до водного дефіциту генетично модифікованих рослин пшениці м'якої (Triticum aestivum L., сорт Зимоярка), що містять гетерологічний ген орнітин- $\delta$-амінотрансферази (Medicago truncatula), на основі аналізу зернової продуктивності, фізіологічних та біохімічних характеристик у трансгенних i нетрансгенних генотипів. Методи. Біохімічні, спектрофотометричні: активність ферменту орнітин- $\delta$ амінотрансферази, вміст вільного L-проліну, вміст фотосинтетичних пігментів; біотехнологічні: Agrobacteriumопосередкована трансформація in planta; фізіологічні: морфометричні показники та елементи структури врожаю; математична статистика. Результати. 3'ясовано, що наявність додаткової копії гена орнітин- $\delta$-амінотрансферази в трансгенних рослинах призводить до підвищення активності цього ферменту: у 1,6 рази в середньому для всіх ліній порівняно 3 нетрансгенними рослинами за умов оптимального водозабезпечення (70 \% від повної вологоємності) та у 1,5 рази - за умов грунтової посухи (30\% повної вологоємності). Однак трансгенні рослини суттєво не відрізнялись від рослин вихідного сорту за вмістом вільного L-проліну ні за умов оптимального водозабезпечення, ні за умов грунтової посухи. Встановлено підвищення сумарного вмісту хлорофілів $(a+b)$ у прапорцевих листках трансгенних рослин за умов оптимального водозабезпечення та за умов посухи, порівняно 3 вихідним генотипом (відповідно, на 5-7 \% та на 8-11\%). Посилена експресія гена орнітин- $\delta$-амінотрансферази в трансгенних рослинах стимулювала ріст коренів як за звичайних, так і за стресових умов: довжина коренів трансформованих рослин перевищувала їх довжину у рослин вихідного сорту на 3,4-3,9 см у варіанті з оптимальним водозабезпеченням та на 4,2-4,6 см - за умов посухи. Вони також характеризувалися більш розвиненою кореневою системою. Маса сухої речовини коренів трансгенних рослин перевищувала вихідний сорт як у контролі (на $23-27 \%$ ), так і за умов посухи (на 37-44 \%). За посухи маса сухої речовини коренів у рослин вихідного сорту зменшилась на $29 \%$, порівняно з оптимальним водозабезпеченням, у ліній - на 11-15 \%. За посухи трансгенні лінії також перевищували нетранс- формовані рослини за кількістю зерен 3 рослини (в середньому для 3 ліній на 26 \%) і за масою зерна (на $22 \%$ ). Трансгенні рослини характеризуються утворенням більшої кількості продуктивних стебел: від 3,2 до 3,4 порівняно 3 2,5 у нетрансгенних рослин при оптимальному водозабезпеченні та 2,7-3,1 проти 2,2 при посусі. Висновки. Таким чином, аналіз генетично модифікованих рослин м'якої пшениці сорту Зимоярка, що містить гетерологічний ген орнітин- $\delta$-амінотрансферази люцерни, за елементами структури врожаю, морфометричними параметрами та вмістом фотосинтетичних пігментів засвідчив їх кращу толерантність до грунтової посухи порівняно з нетрансгенними рослинами. Поліпшення зернової продуктивності рослин трансгенних ліній пшениці 3 додатковою копією гена орнітин- $\delta$-амінотрансферази ми пояснюємо тим, що вони мають краще розвинену кореневу систему (суха маса коренів у них перевищувала вихідний сорт як у контролі (на 23-27\%), так і за умов посухи (на $37-$ $44 \%$ ) та більшу кількість продуктивних пагонів (у середньому для 3 ліній за оптимального водозабезпечення $-3,3$, за посухи $-2,5)$, ніж рослини вихідного сорту (відповідно 2,9 та 2,2).

Ключові слова: пшениця, трансгенні рослини, ген метаболізму проліну, грунтова посуха, фотосинтетичні пігменти, зернова продуктивність.

\section{REFERENCES}

Abass MA, Moradtalab N, Abd-Allah EF, Ahmad P, Hajiboland R. (2016) Plant growth under drought stress: Significance of mineral nutrients. In: Ahmad P (ed). Water Stress and Crop Plants: A Sustainable Approach, vol 2. John Wiley \& Sons, Ltd, pp 650-668.

Ahmed HGM-D, Zeng Y, Yang X, Anwaar HA, Mansha MZ, ChMSh Hanif, K Ikram, A Ullah, Alghanem SMS. (2020) Conferring drought-tolerant wheat genotypes through morpho-physiological and chlorophyll indices at seedling stage. Saudi. J. Biol. Sci. 27(8):2116-2123. https://doi.org/10.1016/j.sjbs.2020.06.019.

Allahverdiyev TI, Talai JM, Huseynova IM, Aliyev JA. (2015) Effect of drought stress on some physiological parameters, yield, y1eld components of durum (Triticum durum desf.) and bread (Triticum aestivum L.) wheat genotypes. Ekin. J. Crop. Breed. Gen. 1-1:50-62.

Anwar A, She M, Wang K, Riaz B, Ye X. (2018) Biological roles of ornithine aminotransferase (OAT) in plant stress tolerance: present progress and future perspectives. Int. J. Mol. Sci. 19(11):3681. doi: 10.3390/ijms19113681.

Anwar A, She M, Wang K, Ye X. (2020) Cloning and molecuar characterization of Triticum aestivum ornithine amino transferase (TaOAT) encoding genes. BMC Plant Biol. 20:187. https://doi.org/10.1186/s12870-020-02396-2.

Bates LS, Waldren RP, Teare ID. (1973) Rapid determination of free proline for water-stress studies. 
DUBROVNA et al.

Plant Soil. 39:205-207. http://dx.doi.org/10.1007/BF 00018060.

Becker SR, Byrne PF, Reid SD. (2016) Root traits contributing to drought tolerance of synthetic hexaploid wheat in a greenhouse study. Euphytica. 207(1):213-224. doi: 10.1007/s10681-015-1574-1.

Brisson N, Gate Ph, Gouache D, Charmet G, Oury F-X, Huard F. (2010) Why are wheat yields stagnating in Europe? A comprehensive data analysis for France. Field Crops Res. 119(1):201-212. https://doi.org/10.1016/j.fcr. 2010.07.012.

Budak H, Hussain B, Khan Z, Ozturk NZ, Ullah N. (2015) From genetics to functional genomics: improvement in drought signaling and tolerance in wheat. Front. Plant Sci. 6:1012. doi: 10.3389/fpls.2015.01012.

Canas RA, Villalobos DP, Diaz-Moreno SM, Cánovas FM, Cantón FR. (2008) Molecular and functional analyses support a role of ornithine- $\delta$-aminotransferase in the provision of glutamate for glutamine biosynthesis during pine germination. Plant Physiol. 148(1):77-88. doi: 10. 1104/pp.108.122853.

da Rocha IM, Vitorello VA, Silva JS, Ferreira-Silva SL, Viégas RA, Silva EN, Silveira JAG. (2012) Exogenous ornithine is an effective precursor and the $\delta$-ornithine amino transferase pathway contributes to proline accumulation under high $\mathrm{N}$ recycling in salt-stressed cashew leaves. J. Plant Physiol. 169(1):41-49. doi: 10.1016/j. jplph.2011.08.001.

Delauney AJ, Hu CA, Kishor PB, Verma DP. (1993) Cloning of ornithine delta-aminotransferase cDNA from Vigna aconitifolia by transcomplementation in Escherichia coli and regulation of proline biosynthesis. J. Biol. Chem. 268 (25):18673-18678. doi: 10.1016/S0021-9258(17)46682-8.

Dubrovna OV, Stasik OO, Priadkina GO, Zborivska OV, Sokolovska-Sergiienko OG. (2020) Resistance of genetically modified wheat plants, containing a double-stranded RNA suppressor of the proline dehydrogenase gene, to soil moisture deficiency. Agric. Sci. Pract. 7(2):24-34. doi: 10.15407/agrisp7.02.024.

Farooq M, Hussain M, Siddique KHM. (2014) Drought stress in wheat during flowering and grain-filling periods. Crit. Rev. Plant Sci. 33(4):331-349 doi: 10.1080/ 07352689.2014.875291.

Fukao T, Xiong L. (2013) Genetic mechanisms conferring adaptation to submergence and drought in rice: simple or complex? Curr. Opin. Plant Biol. 16(2):196-204. doi: 10.1016/j.pbi.2013.02.003.

Funck D, Stadelhofer B, Koch W. (2008) Ornithine-deltaaminotransferase is essential for arginine catabolism but not for proline biosynthesis. BMC Plant Biol. 8:40. doi: 10.1186/1471-2229-8-40.

Gerasimova SV, Kochetov AV, Ibragimova SS, Shumnyi VK. (2011) Functions of delta-ornithine-aminotransferase in plants. Adv. Curr. Biol. 131(6):531-542 (in Russian).

Gerasimova SV, Kolodyazhnaya YaS, Titov SE, Romanova
AV, Koval' VS, Kochetov AV, Shumnyi VK. (2010) Tobacco transformants expressing the Medicago truncatula ornithine aminotransferase cDNA. Russ. J. Genet. 46(7): 1000-1003. doi: 10.1134/S102279541007015X.

Gilev VYu. (2012) Soil physics. Educational - methodical instructions for field practice. Perm. $37 \mathrm{p}$.

Goncharuk AN, Bavol AV, Dubrovna OV. (2015) Agrobacterium-mediated transformation of common wheat in planta using the ornithine aminotransferase gene. Factors in experimental evolution of organisms. 17: 131-135.

Guan C, Huang YH, Cen HF, Cui X, Tian D-Y, Zhang Y-W. (2019) Overexpression of the Lolium perenne L. delta1-pyrroline 5-carboxylate synthase (LpP5CS) gene results in morphological alterations and salinity tolerance in switchgrass (Panicum virgatum L.). Plos One. 14: e0219669. https://doi.org/10.1371/journal.pone.0219669. Guerzoni JTS, Belintani NG, Moreira RMP, Hoshino AA, DS Domingues, JCB Filho, Vieira LGE. (2014) Stressinduced $\Delta 1$-pyrroline-5-carboxylate synthetase (P5CS) gene confers tolerance to salt stress in transgenic sugarcane. Acta Physiol. Plant. 36(9):2309-2319. https:// doi.org/10.1007/s11738-014-1579-8.

Hein JA, Sherrard ME, Manfredi KP, Abebe T. (2016) The fifth leaf and spike organs of barley (Hordeum vulgare L.) display different physiological and metabolic responses to drought stress. BMC Plant Biol. 16:248. doi: 10.1186/ s12870-016-0922-1.

Hiei Y, Ishida Y, Komari T. (2014) Progress of cereal transformation technology mediated by Agrobacterium tumefaciens. Front. Plant Sci. 5:628. doi: 10.3389/fpls. 2014.00628.

Kalamaki MS, Merkouropoulos G, Kanellis AK. (2009) Can ornithine accumulation modulate abiotic stress tolerance in Arabidopsis? Plant Signal. Behav. 4(11):1099-1101. doi: 10.4161/psb.4.11.9873.

Kapoor D, Bhardwaj S, Landi M, Sharma A, Ramakrishnan M, Sharma A. (2020) The impact of drought in plant metabolism: How to exploit tolerance mechanisms to increase crop production. Appl. Sci. 10(16):5692. https:// doi.org/10.3390/app10165692 .

Kaur G, Asthir B. (2015) Proline: a key player in plant abiotic stress tolerance. Biol. Plant. 59(4):609-619. https://doi. org/10.1007/s10535-015-0549-3.

Khan MS, Ahmad D, Khan MA. (2015) Utilization of genes encoding osmoprotectants in transgenic plants for enhanced stress tolerance. Electron. J. Biotechnol. 18(4):257-266. doi: 10.1016/j.ejbt.2015.04.002.

Komisarenko AG, Mykhalska SI, Kurchii VM. (2019) Productivity of winter wheat plants with the additional copy of ornithine- $\delta$-aminotransferase gene under water deficit conditions. Factors in experimental evolution of organisms. 25:247-252. https://doi.org/10.7124/FEEO.v25.1171.

Laidig F, Piepho HP, Rentel D, Drobek T, Meyer U, Huesken A. (2017) Breeding progress, environmental variation 
and correlation of winter wheat yield and quality traits in German official variety trials and on-farm during 19832014. Theor. Appl. Genet. 130(1):223-245. doi: 10.1007/ s00122-016-2810-3.

le Roux ML, Burger NFV, Vlok M, Kunert KJ, Cullis CA, Botha A-M. (2020) Wheat Line "RYNO3936" is associated with delayed water stress-induced leaf senescence and rapid water-deficit stress recovery. Front. Plant Sci. 11:1053. doi: 10.3389/fpls.2020.01053.

Liang X, Zhang L, Natarajan SK, Becker DF. (2013) Proline mechanisms of stress survival. Antioxid Redox Signal. 19(9):998-1011. doi: 10.1089/ars.2012.5074.

Liu C, Xue Z, Tang D, Shen Y, Shi W, Ren L, Du G, Li Y, Cheng $Z$. (2018) Ornithine $\delta$-aminotransferase is critical for floret development and seed setting through mediating nitrogen reutilization in rice. Plant J. 96(4):842-854. doi: $10.1111 /$ tpj. 14072 .

Lopes MS, Reynolds MP. (2010) Partitioning of assimilates to deeper roots is associated with cooler canopies and increased yield under drought in wheat. Funct. Plant Biol. 37(2):147-156 doi: 10.1071/FP09121.

Madan S, Nainawatee HS, Jain RK, Chowdhury JB. (1995) Proline and proline metabolizing enzymes in vitro selected NaCl-tolerant Brassica juncea L. under salt stress. Ann. Bot. 76(1):51-57. https://www.jstor.org/ stable/42764614.

Majumdar R, Barchi B, Turlapati SA, Gagne M, Minocha R, Long S, Minocha S. (2016) Glutamate, ornithine, arginine, proline, and polyamine metabolic interactions: The pathway is regulated at the posttranscriptional level. Front. Plant Sci. 7:78. doi: 10.3389/fpls.2016.00078.

Martinelli T, Whittaker A, Bochicchio A, Vazzana C, Suzuki A, Masclaux-Daubresse C. (2007) Amino acid pattern and glutamate metabolism during dehydration stress in the 'resurrection' plant Sporobolus stapfianus: a comparison between desiccation-sensitive and desiccationtolerant leaves. J. Exp. Bot. 58(11):3037-3046. doi: 10. 1093/jxb/erm161.

Mattioli R, Costantino P, Trovato M. (2009) Proline accumulation in plants: not only stress. Plant Signal. Behav. 4(11):1016-1018. doi: 10.4161/psb.4.11.9797.

Morgun VV, Kiriziy DA, Shadchina TM. (2010) Ecophysiological and genetical aspects of crops adaptation to global climate changes. Physiol. Biochem. Cult. Plants. 42(1):3-22 (in Russian).

Morgun VV, Stasik OO, Kiriziy DA, Sokolovska-Sergiienko OG, Makharynska NM. (2019) Effects of drought at different periods of wheat development on the leaf photosynthetic apparatus and productivity. Regul. Mech. Biosyst. 10(4):400-408. https://doi. org/10.15421/021961.

Narusaka M, Shiraishi T, Iwabushi M, Narusaka Y. (2010) The floral inoculation protocol: a simple Arabidopsis thaliana transformation method modified from floral dipping. Plant Biotechnol. 27(4):349-351. doi: 10.5511/ plantbiotechnology.27.349.

Raza A, Razzaq A, Mehmood SS, Zou X, ZhangX, Lv Y, Xu $J$. (2019) Impact of climate change on crops adaptation and strategies to tackle its outcome: A Review. Plants. 8(2):34. doi: 10.3390/plants8020034.

Rizzi Y, Monteoliva M, Fabro G, Grosso C, Laróvere L, Alvarez M. (2015) P5CDH affects the pathways contributing to Pro synthesis after ProDH activation by biotic and abiotic stress conditions. Front. Plant Sci. https://doi. org/10.3389/fpls.2015.00572.

Roosens NH, Bitar FA, Loenders K. (2002) Overexpression of ornithine-aminotransferase increases proline biosynthesis and confers osmotolerance in transgenic plants. Mol. Breed. 9(2):73-80. https://doi.org/10.1023/A: 1026791932238.

Roosens NH, Thu TT, Iskandar HM, Jacibs M. (1998) Isolation of the ornithine- $\delta$-aminotransferase cDNAand effect of salt stress on its expression in Arabidopsis thaliana. Plant Physiol. 117(1):263-271. doi: 10.1104/ pp.117.1.263.

Sadras VO, Calderini DF (eds). (2015) Crop physiology: applications for genetic improvement and agronomy. Academic Press, London. doi: 10.1016/B978-0-12417104-6.00001-7.

Sambrook J, Fritsch EF, Maniatis T. (1989) Molecular cloning: A laboratory manual. New York: Cold Spring Harbor Laboratory Press, Cold Spring harbor, New York 3:A2.2.

Sánchez E, López-Lefebre LR, García PC, Rivero RM, Ruiz $J M$, Romero L. (2001) Proline metabolism in response to highest nitrogen dosages in green bean plants (Phaseolus vulgaris L. cv. Strike). J. Plant Physiol. 158(5):593-598. doi.org/10.1078/0176-1617-00268.

Senthil-Kumar M, Mysore KS. (2012) Ornithine-delta-aminotransferase and proline dehydrogenase genes play a role in non-host disease resistance by regulating pyrroline-5carboxylate metabolism-induced hypersensitive response. Plant Cell Environ. 35(7):1329-1343. doi: 10.1111/j. 1365-3040.2012.02492.x.

Sharma S, Verslues PE. (2010) Mechanisms independent of abscisic acid (ABA) or proline feedback have a predominant role in transcriptional regulation of proline metabolism during low water potential and stress recovery. Plant Cell Environ. 33(11):1838-1851. doi: 10. 1111/j.1365-3040.2010.02188.x.

Stewart CN, Via LE. (1993) A rapid CTAB DNA isolation technique useful for RAPD fingerprinting and other PCR applications. Biotechnol. Tech. 14(5):748-750. PMID: 8512694.

Stránská J, Tylichová M, Kopecny D, Snégaroff J, Šebela M. (2010) Biochemical characterization of pea ornithine$\delta$-aminotransferase: Substrate specificity and inhibition by di- and polyamines. Biochimie. 92(8):940-948. doi: 10.1016/j.biochi.2010.03.026. 


\section{DUBROVNA et al.}

Szabados L, Savoure A. (2010) Proline: a multifunctional amino acid. Trends Plant Sci. 15(2):89-97. doi: 10.1016/j. tplants.2009.11.09.

Tran LSP, Nakashima K, Shinozaki K, Yamaguchi-Shinozak $K$. (2007) Plant gene networks in osmotic stress response: From genes to regulatory networks. Methods Enzymol. 428:109-128. doi: 10.1016/S0076-6879(07)28006-1.

Tuberosa R, Salvi S. (2006) Genomics-based approaches to improve drought tolerance of crops. Trends Plant Sci. 11(8):405-412. doi: 10.1016/j.tplants.2006.06.003.

Vahdati K, Lotfi N. (2013) Abiotic stress tolerance in plants with emphasizing on drought and salinity stresses in walnut. Vahdati K (ed) In: Abiotic Stress. Plant Res. Appl. Agric. doi: 10.5772/56078.

Wasson AP, Richards RA, Chatrath R, Misra SC, Prasad SVS, Rebetzke GJ, Kirkegaard JA, Christopher J, Watt $M$. (2012) Traits and selection strategies to improve root systems and water uptake in water-limited wheat crops. J. Exp. Bot. 63(9):3485-3498. doi: 10.1093/jxb/ers111.

Wellburn AP. (1994) The spectral determination of chlorophyll $a$ and $b$, as well as carotenoids using various solvents with spectrophotometers of different resolution. J. Plant Physiol. 144(3):307-313. https://doi.org/10.1016/S01761617(11)81192-2.

Wu L, Fan Z, Guo L. (2003) Over-expression of an Arabidopsis OAT gene enhances salt and drought tolerance in transgenic rice. Chin. Sci. Bull. 48(23):2594-2600. https://doi.org/10.1360/03wc0218.

Xue X, Liu A, Hua X. (2009) Proline accumulation and transcriptional regulation of proline biosynthesis and degradation in Brassica napus. BMB Rep. 42(1):28-34. doi: 10.5483/bmbrep.2009.42.1.028.

Yang S, Vanderbeld B, Wan J, Huang Y. (2010) Narrowing down the targets: Towards successful genetic engineering of drought-tolerant crops. Mol. Plant. 3(3):469-490. doi: $10.1093 / \mathrm{mp} / \mathrm{ssq} 016$.

You J, Ни H, Xiong L. (2012) An ornithine $\delta$-aminotransferase gene OsOAT confers drought and oxidative stress tolerance in rice. Plant Sci. 197:59-69. doi: 10.1016/j.plant sci.2012.09.002.

Zadoks JC, Chang TT, Konzak CF. (1974) A decimal code for the growth stages of cereals. Weed Res. 14:415-421. https://doi.org/10.1111/j.1365-3180.1974.tb01084.x .

Zale J, Agarwal S, Loar S, Steber CM. (2009) Evidence for stable transformation of wheat by floral dip in Agrobacterium tumefaciens. Plant Cell Rep. 28(6):903913. doi: 10.1007/s00299-009-0696-0.

Zhang J, Zhang S, Cheng M, Jiang H, Zhang X, Peng C, Lu $X$, Zhang M, Jin J. (2018) Effect of drought on agro-nomic traits of rice and wheat: A meta-analysis. Int. J. Res. Public. Health. 15(5):839. doi: 10.3390/ ijerph15050839. 